\title{
Interpretation of wireline log data for reservoir characterization of the Rashidpur Gas Field, Bengal Basin, Bangladesh.
}

\author{
A.R.M.T Islam ${ }^{1}$, M. A Habib ${ }^{2}$, M. T Islam ${ }^{3}$, M. R Mita ${ }^{4}$ \\ ${ }^{1}$ Lecturer, Dept. of Disaster Management, Begum Rokeya University, Rangpur, 5400, Bangladesh \\ ${ }^{2}$ Asst. Director, Geological Survey of Bangladesh, Dhaka, 1000, Bangladesh \\ ${ }^{3}$ Lecturer, Dept. of Political Science, Begum Rokeya University, Rangpur, 5400, Bangladesh \\ ${ }^{4}$ B.Sc. Dept. of Disaster Management, Begum Rokeya University, Rangpur, 5400, Bangladesh
}

\begin{abstract}
The study was embodied with quantitative analysis of petrophysical parameters of the gas zone to characterize the reservoirs in the Rashidpur well-4 of the Rashipdur Gas Field, Bangladesh. 20 permeable zones were identified in the study. Among these, 4 zones were gas-bearing and the rest zones were water. Hydrocarbon type might be gas which was positively indicated comparatively high resistivity, low neutron and low density log responses in these zones than that of the water zones. Average porosity of these zones ranged from $18-27 \%$, water saturation $17-40 \%$, hydrocarbon saturation $60-82 \%$ and permeability ranged from 50.94 $m D$ to $363 \mathrm{mD}$. Hydrocarbon is moveable in the reservoir because all the value is less than 0.70 indicate by hydrocarbon moveavility index. Average bulk volume of water ranged from 0.04 to 0.13 . All the calculated values support that lithology are fine to very fine-grained sandstone and is at irreducible water saturation. The zone-4 was shown comparatively highest thickness, porosity, hydrocarbon saturation and permeability than other zones. The study can be concluded that these hydrocarbon-bearing zones are potential for gas production and good reservoir bearing formation.
\end{abstract}

Keywords: Petrophysical parameter, Rashidpur Gas Field, Permeable zone, Hydrocarbon moveable and Reservoir potential

\section{Introduction}

Petrophysical parameters are the most useful characteristics of reservoir for development and production of the drill well and estimation of reserves in any gas field. Reservoir characterization is the process of mapping a reservoir's thickness, net to gross ratio, pore fluid, porosity, permeability and water saturation [1]. Different types of gamma ray (GR), spontaneous potential (SP), resistivity, neutron and density log are helped to define physical characteristics of the reservoirs such as porosity, saturation, hydrocarbon moveability and permeability [2]. These data are used to identify permeable zones for hydrocarbon with depth and thickness of the zones and to distinguish interfaces of oil, gas or water in a reservoir. All these are essential for estimation of hydrocarbon reserves. Islam et al., [3-6] were studied in shaly-sand reservoir of Bengal Basin, Bangladesh by petrophysical analysis. Rahman et al. [7] was carried out by in the reservoir sand of Titas-15 well, Bangladesh using wireline log interpretation. These earlier studies were motivated by the fact that gas-bearing reservoir of Bangladesh was taken special attention due to its economic interest.

In this regard, the present research work was focused on wireline log data to characterize the reservoir of the Rashidpur well-4. The outcome of this study is to characterize the reservoir using well logs and estimated petrophysical parameter of hydrocarbon-bearing zones of the Rashidpur Gas Field, Bangladesh. The Rashidpur Gas Field is situated in the south central part of the Sylhet Trough under Bahubal Upazila of Habiganj District and flanked by the Khowai syncline in the west and the Srimangal syncline in the east. The area is located in between the latitudes $24^{\circ} 32^{\prime \prime} \mathrm{N}$ to $24^{\circ} 18^{\prime \prime} \mathrm{N}$ and the longitudes $91^{\circ} 30^{\prime \prime} \mathrm{E}$ to $91^{\circ} 43^{\prime \prime} \mathrm{E}$ (Fig.1).

\section{Geologic Setting}

Bengal Basin of Bangladesh is a young prolific hydrocarbon basin in the world [8]. The Rashidpur structure is situated in the south central part of the Sylhet Trough [9]. The Sylhet Trough is a major sub-basin of the Bengal Basin which situated in northeastern part of Bangladesh. The Sylhet Trough might have been formed at the late orogenic stage due to subsidence along the Dauki Fault system and Plio-pleistocene uplift of the Shillong Massif [10].The N-S trending Rashidpur structure is a narrow, elongated and compressed asymmetric anticline. As an asymmetrical anticline the eastern flanks of the structure is steeper $\left(20^{\circ}-25^{\circ}\right)$ than the western flanks [10]. The eastern part of the structure is thrust faulted with a throw of about $500 \mathrm{~m}$. The Lower to Middle Miocene Surma Group, consisting of the underlying Bhuban Formation and the overlying Boka Bil Formation were deposited during repeated transgression and regression phases of marine environment. This unit is well developed in the Eastern Folded Belts including Chittagong Hill Tracts and Sylhet Trough (Fig.2). 




Figure 1 Map showing the location of the Rashidpur Gas Field (After modified [8])

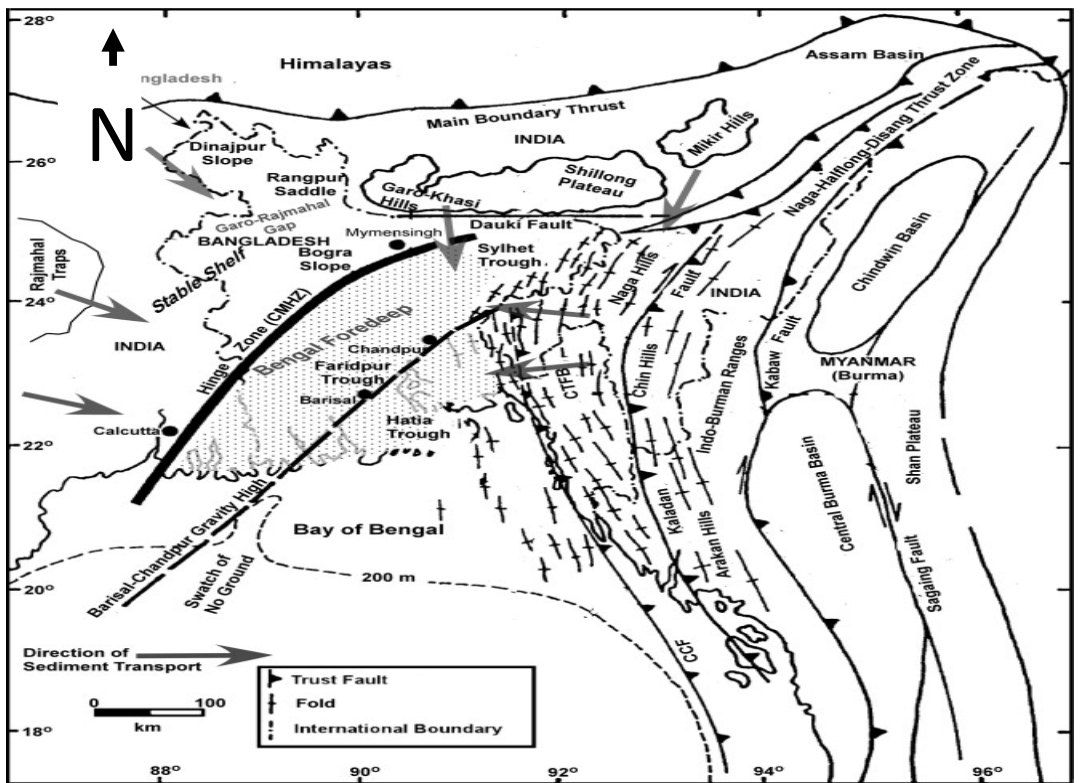

Figure 2 Map showing the regional tectonics elements of the Bengal Basin and surrounding areas (Modified from [8], [11])

\section{Materials And Methods}

Wireline log data for the study was collected from the Bangladesh Petroleum Exploration and Production Company Ltd. (BAPEX). Wireline logs (GR, SP, N, D, MSFL and ILD) of the Rashidpur well-4 have been regenerated from hard copies and calculated to determine the petrophysical parameters such as porosity, water and hydrocarbon saturation and permeability etc. Digitization of wireline log data was carried out by Excel software. The procedure for calculation of petrophysical parameters are as follows:

3.1 Volume of shale calculation: The primary step is required to determine the shale volume from a gamma ray (GR) $\log [12]$.

$I_{G R}=\frac{G R_{\log }-G R_{\min }}{G R_{\operatorname{mix}}-G R_{\min }}$.

Shale volume can be calculated from the gamma ray index $\left(I_{G R}\right)$ for Tertiary rocks [13]. Calculate shale volume is written as: 
$V_{s h}=0.083\left[2^{3.7 \times I_{G R}}-1.0\right]$

3.2 Porosity calculation: After calculation of the shale volume $\left(V_{s h}\right)$, it is needed to correct the shale effect for porosity logs. To calculate porosity from neutron and density logs [13]:

$\emptyset_{D e n}=\left(\frac{\rho_{m a}-\rho_{b}}{\rho_{m a}-\rho_{f}}\right)-V_{s h}\left(\frac{\rho_{m a}-\rho_{s h}}{\rho_{m a}-\rho_{f}}\right)$.

$\emptyset_{\text {Ncorr }}=\emptyset_{N}-\left[\left(\frac{\emptyset_{N c h}}{0.45}\right) \times 0.30 \times V_{s h}\right]$

Calculation of porosity value is also obtained from corrected Neutron-Density logs [12]

$\emptyset_{\text {Dcorr }}=\emptyset_{D}-\left[\left(\frac{\emptyset_{N c l}}{0.45}\right) \times 0.13 \times V_{s h}\right]$.

$\emptyset_{N-D=} \sqrt{\frac{\emptyset_{N_{\text {corr }}{ }^{2}+}}{2.0} \emptyset_{D_{\text {corr }}{ }^{2}}}$

3.3 Saturation calculation: Water saturation has been calculated after porosity correction for shale effect. The following three equations of water saturation calculation are commonly used for gas reservoir:

$S_{w}=\frac{\frac{V_{s h}}{R_{s h}}+\sqrt{\left(\frac{V_{s h}}{R_{s h}}\right)^{2}+\frac{\phi^{2}}{0.2 \times R_{W} \times\left(1.0-V_{s h}\right) \times R_{t}}}}{\frac{\phi^{2}}{0.4 \times R_{W} \times\left(1.0-V_{s h}\right) \times R_{t}}}$.

Calculation of formation water resistivity of gas-bearing zone by the formula [14].

$R_{w}=10\left\{\frac{S S P}{K}+\log R_{w}\right\}$

3.4 Permeability calculation: Permeability value has been estimated from the following equation by [15]

$k=\left(\frac{c \times \phi^{2 w}}{W^{4} \times\left(\frac{R_{w}}{R_{\text {tirr }}}\right)}\right)^{2}$.

Where, $\mathrm{W}=\left[(3.75-\varphi)+\left\{\frac{\left[\log \left(\frac{R_{W}}{R_{\text {tirr }}}\right)+2.2\right]^{2}}{2}\right\}\right]^{1 / 2}$

$\mathrm{c}=23+465 \rho_{h}-188 \rho_{h}^{2}$

3.5 Hydrocarbon moveability index calculation: hydrocarbon moveability index is a ratio of the uninvaded zone and flushed zone which estimated by the following equation [16]:

$\frac{S_{w}}{S_{x o}}=\left[\frac{R_{x o} \times R_{w}}{R_{t} \times R_{m f}}\right]^{1 / 2}$.

3.6 Bulk volume of water calculation: BVW of the hydrocarbon-bearing zone has been calculated using equation [17]:

$\mathrm{BVW}=S_{w} \times \emptyset$.

\section{Finding And Discussions}

4.1 Permeable Zones Identification: Permeable zones were identified with the help of high SP and low GR log responses in the study well. But it was either water-bearing or hydrocarbon-bearing zone. Low resistivity, low SP, high GR log values were shown by water-bearing permeable zones. But high resistivity, high SP and low GR values were represented hydrocarbon-bearing permeable zones [2]. Four hydrocarbon-bearing zones were identified within the Miocene sequence of the Rashidpur well-4 and remaining was water-bearing (Table 1). 
Table 1 Shows permeable zones of the Rashidpur well-4 in the Rashidpur Gas Field, Bangladesh.

\begin{tabular}{|l|l|l|l|}
\hline Zone No. & Fluid Type & Depth Range $(\mathrm{m})$ & Thickness $(\mathrm{m})$ \\
\hline 1 & Water-bearing & $1374-1402$ & 28 \\
\hline 2 & Hydrocarbon-bearing & $1447-1523$ & 76 \\
\hline 3 & Water-bearing & $1534-1550$ & 16 \\
\hline 4 & Water-bearing & $1555-1565$ & 10 \\
\hline 5 & Water-bearing & $1575-1595$ & 20 \\
\hline 6 & Water-bearing & $1635-1670$ & 35 \\
\hline 7 & Water-bearing & $1718-1740$ & 22 \\
\hline 8 & Water-bearing & $1760-1780$ & 20 \\
\hline 9 & Water-bearing & $1795-1805$ & 10 \\
\hline 10 & Water-bearing & $1855-1885$ & 30 \\
\hline 11 & Water-bearing & $1930-1960$ & 30 \\
\hline 12 & Water-bearing & $1962-1985$ & 23 \\
\hline 13 & Water-bearing & $2060-2090$ & 30 \\
\hline 14 & Water-bearing & $2180-2190$ & 10 \\
\hline 15 & Water-bearing & $2215-2225$ & 10 \\
\hline 16 & Water-bearing & $2314-2335$ & 21 \\
\hline 17 & Hydrocarbon-bearing & $2337-2350$ & 13 \\
\hline 18 & Water-bearing & $2405-2440$ & 35 \\
\hline 19 & Hydrocarbon-bearing & $2466-2483$ & 17 \\
\hline 20 & Hydrocarbon-bearing & $2668-2732$ & 64 \\
\hline
\end{tabular}

4.2 Hydrocarbon-bearing Zones Identification: Hydrocarbon-bearing zones of the Rashidpur well-4 were identified by using conventional SP, GR, resistivity (MSFL; ILD), neutron and density logs. These zones were identified depending on the very high values of the resistivity logs comparing to water-bearing zones, high values of SP log and its deflection from the shale base line, low values of GR log, very low density and neutron $\log$ response [18] (Table 1; Figs. 4, 5, 6 and 7 ). Four hydrocarbon-bearing zones were identified from the depth ranged from $1447 \mathrm{~m}$ to $1523 \mathrm{~m} ; 2337 \mathrm{~m}$ to $2350 \mathrm{~m} ; 2466 \mathrm{~m}$ to $2483 \mathrm{~m}$ and $2668 \mathrm{~m}$ to $2732 \mathrm{~m}$ having average thickness of hydrocarbon-bearing zones were presented in the figure 3 .

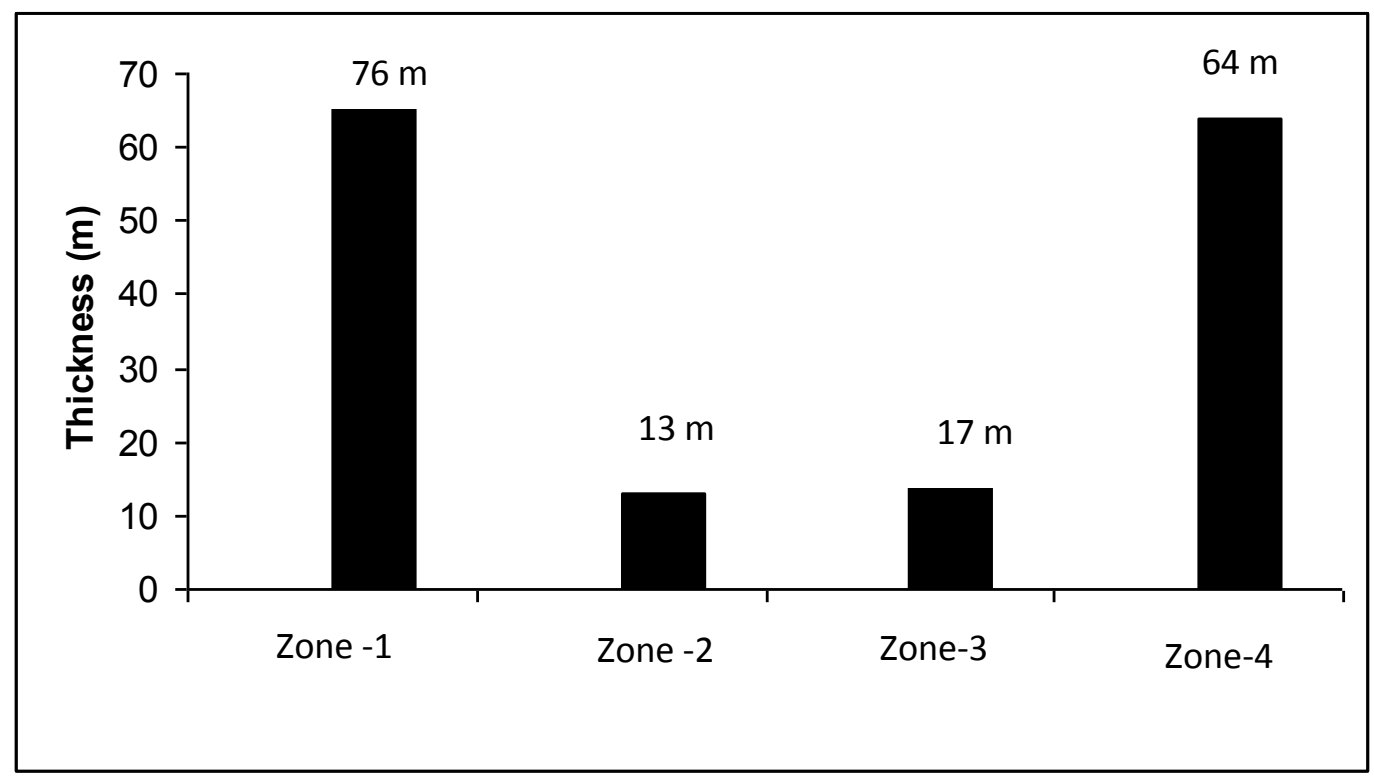

Figure 3 Average thickness distributions of hydrocarbon-bearing zone-1, 2, 3 and 4. 


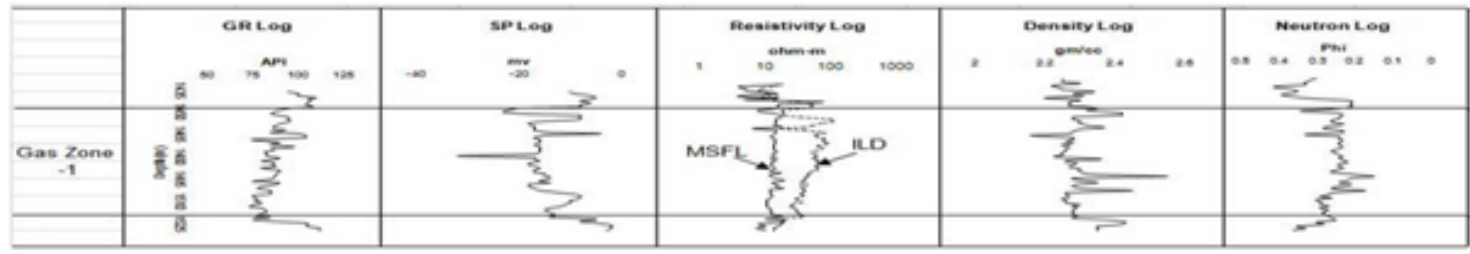

Figure 4 Composite log response of the gas zone-1 of the Rashidpur well-4 in the Rashidpur Gas Field

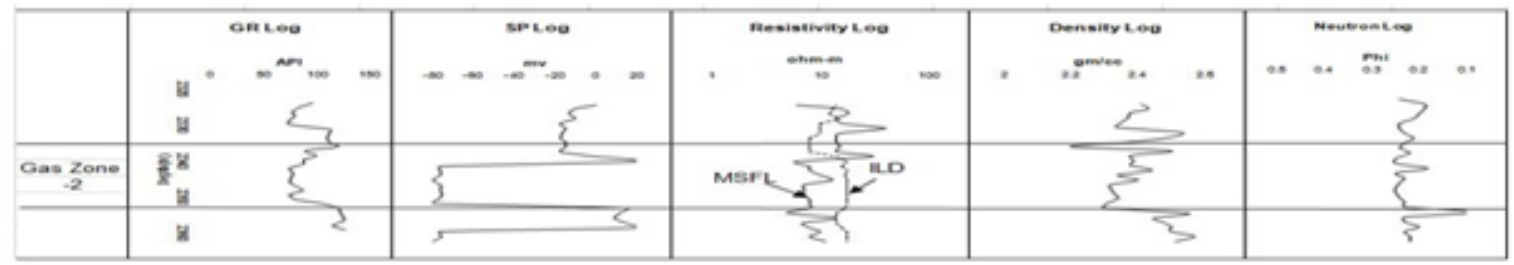

Figure 5 Composite log response of the gas zone- 2 of the Rashidpur well- 4 in the Rashidpur Gas Field

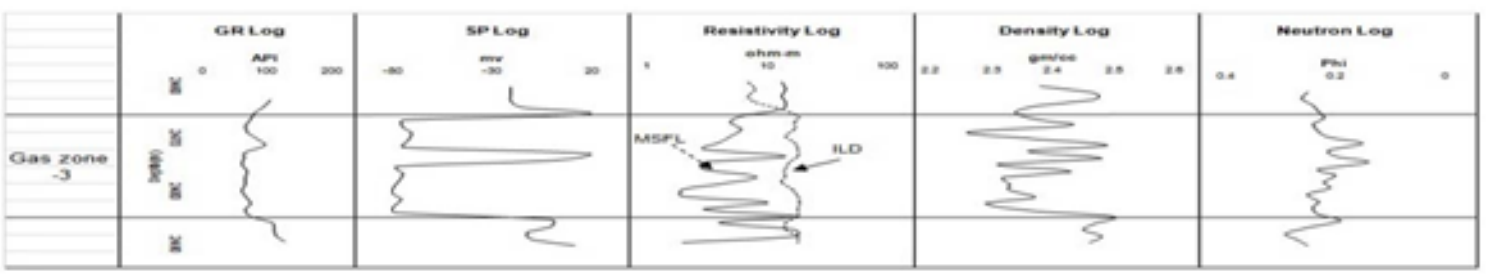

Figure 6 Composite log response of the gas zone-3 of the Rashidpur well-4 in the Rashidpur Gas Field

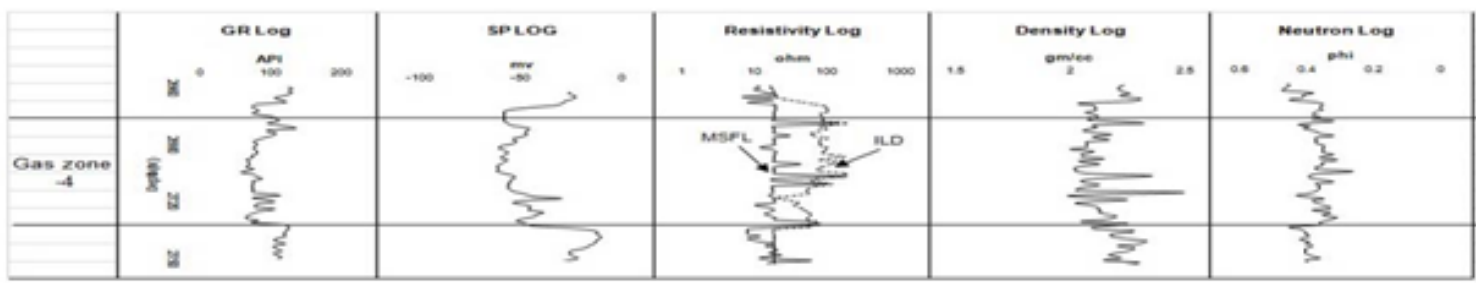

Figure 7 Composite log response of the gas zone- 4 of the Rashidpur well-4 in the Rashidpur Gas Field



Figure 8 Average porosity values of the gas zone-1, 2, 3 and 4 .

4.3 Volume of Shale of Hydrocarbon-bearing Zones: Volume of shale is used to characterize the shale distribution of a reservoir. Volume of shale is also indicating lithology of reservoir rock types. The volumes of shale values were low within the hydrocarbon- bearing zones which presented in the figures $9,10,11$ and 12 . Similar observation made by Islam et al., [3-4].

4.4 Porosity of Hydrocarbon-bearing Zones: The porosity calculation is a very important for determining fluid saturation in the reservoir evaluation [19]. The average porosity value of hydrocarbon-bearing zones-1, 2, 
3 and 4 were presented in the figure 8 . The porosity value of zone- 4 was higher than other zones. The porosity values indicate that the hydrocarbon-bearing zones were good in categories (Figs. 9, 10, 11 and 12).

4.5 Saturation of Hydrocarbon-bearing Zones: Hydrocarbon-bearing zone has not been calculated using Archie (1942) equation because the equation is valid for clean sandstone. The average water saturation of hydrocarbon-bearing zones were calculated as ave. $27 \%$, ave. $37 \%$, ave. $44 \%$ and ave. $17 \%$ respectively and converted to the average hydrocarbon saturation estimated as ave. $72 \%$, ave. $62 \%$, ave. $60 \%$ and ave. $82 \%$ respectively (Fig. 9, 10, 11, 12 and 13). The hydrocarbon saturation value indicates that the reservoir is productive, when the value exceeds $60 \%$ [2]. Islam et al., [5-6] also got same result in the other gas field of Bengal Basin.

4.6 Hydrocarbon Moveability Index $\left(S_{w} / S_{x o}\right)$ : Hydrocarbon moveability index $\left(S_{w} / S_{x o}\right)$ is the ratio between water saturation of uninvaded zone $\left(S_{w}\right)$ to the water saturation of flushed zone $\left(S_{x o}\right)$. The Sw/Sxo value is equal or greater than 1.0 indicates that hydrocarbon is not moveable, if the value is less than 0.7 indicate a moveable hydrocarbon condition [12]. Archie's [16] formula has been used for the calculation of hydrocarbon moveability index. All these values of hydrocarbon moveability of these zones are less than 0.7 , which indicates that the hydrocarbon of these zones is moveable (Table 2).

4.7 Bulk Volume of Water of Hydrocarbon-bearing Zones: BVW indicate the formation is at irreducible water saturation or not. If the BVW ranges from 0.035 to 0.07 , the grain size of the sand is fine to very finegrained [18]. When value of BVW is constant or close to constant with some minor scattering, the formation becomes homogeneous and close to irreducible water saturation [20]. It also indicates that the grain size of the reservoir (Table 2).

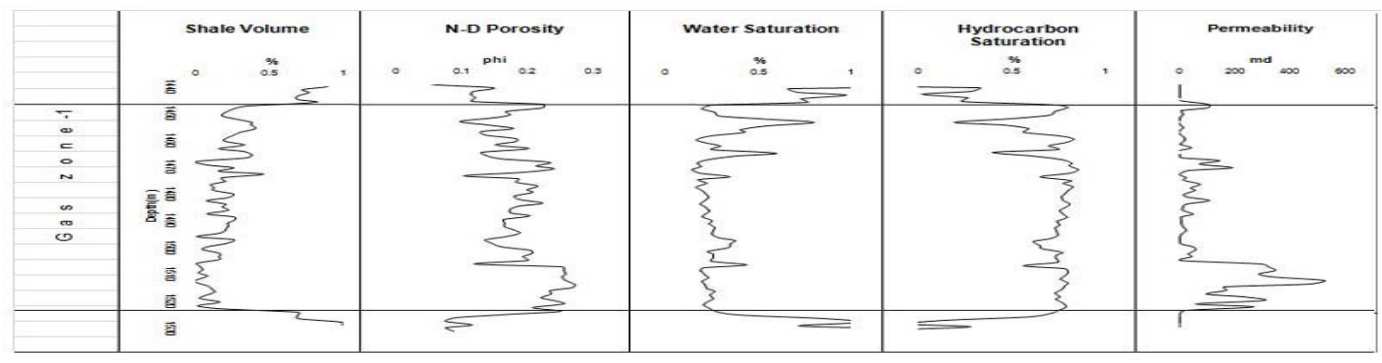

Figure 9 Graphical presentations of petrophysical parameter of the gas zone-1 of the Rashidpur well-4.

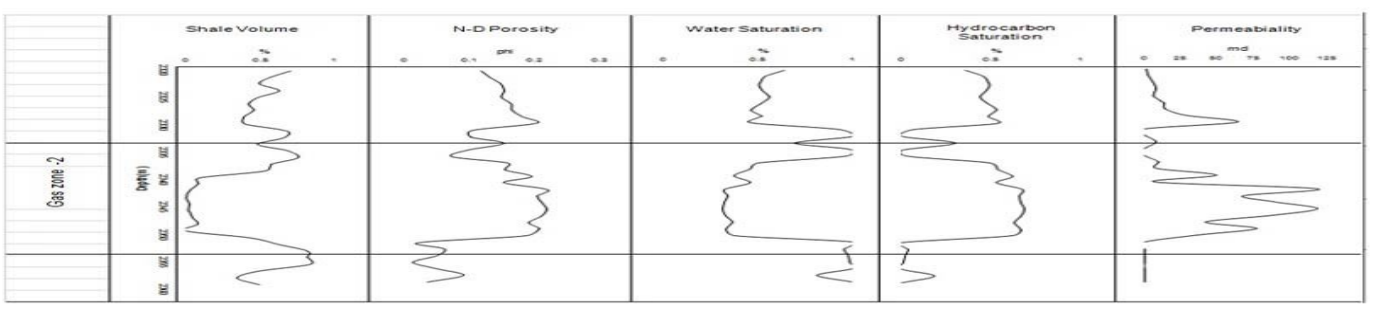

Figure 10 Graphical presentations of petrophysical parameter of the gas zone-2 of the Rashidpur well-4.

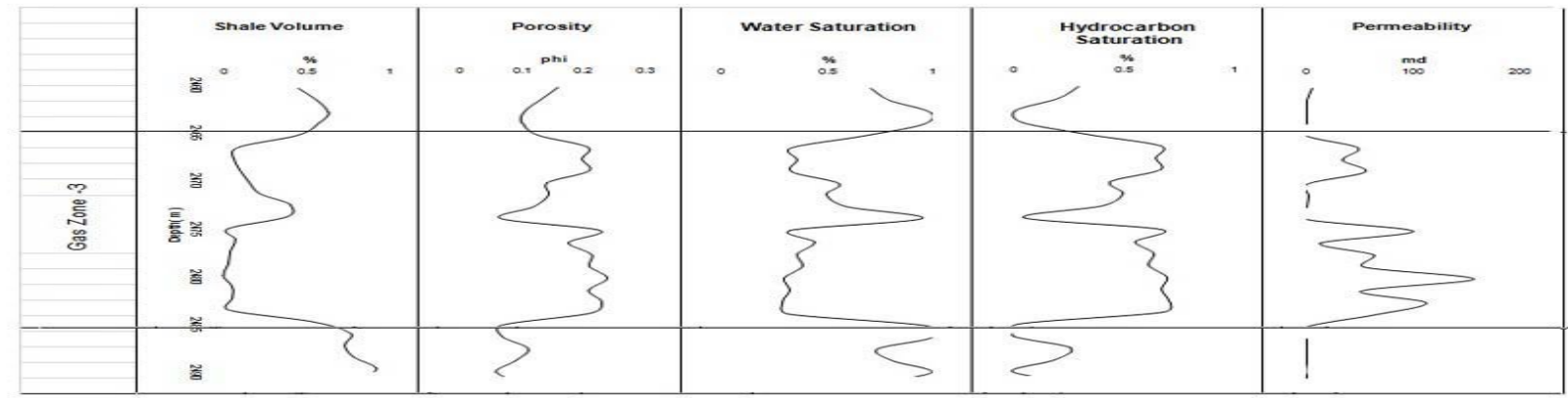

Figure 11 Graphical presentations of petrophysical parameter of the gas zone-3 of the Rashidpur well-4. 




Figure 12 Graphical presentations of petrophysical parameter of the gas zone-4 of the Rashidpur well-4

4.8 Permeability of Hydrocarbon-bearing Zones: Permeability values of hydrocarbon-bearing zones were calculated using formula [15]. Permeability values of these zones ranged from 4.69-525 mD, 7.66-118 mD, 94$157 \mathrm{mD}$ and 106-820 $\mathrm{mD}$ respectively. So, all calculated value of permeability indicated that good reservoirs potential according to observation made by [2] (Fig. 9, 10, 11, 12 and 14).



Figure 13 Average hydrocarbon saturation values of the gas zone-1, 2, 3 and 4.

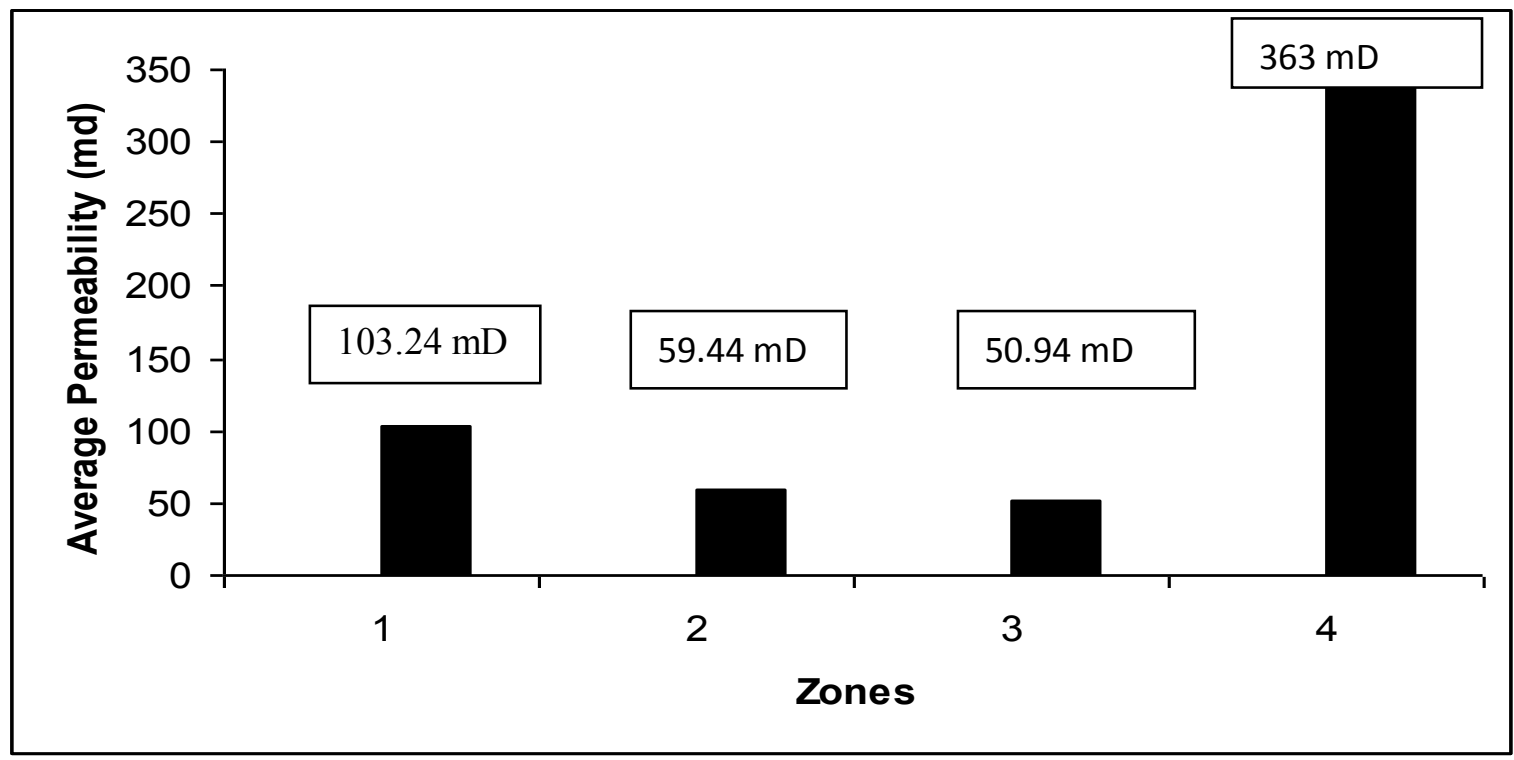

Figure 14 Average permeability values of the gas zone-1, 2, 3, and 4 . 
Table 2 presents the hydrocarbon moveability index and bulk volume of water of the gas zones in the Rashidpur well-4.

\begin{tabular}{|l|l|l|l|l|l|l|}
\hline Zone No. & Depth Range $(\mathrm{m})$ & $\begin{array}{l}\text { Thickness } \\
(\mathrm{m})\end{array}$ & Sw/Sxo Range & $\begin{array}{l}\text { Average } \\
\text { Sw/Sxo }\end{array}$ & BVW Range & Average BVW \\
\hline 1 & $1447-1523$ & 76 & $0.09-0.38$ & 0.14 & $0.065-0.266$ & 0.13 \\
\hline 2 & $2337-2350$ & 13 & $0.13-0.25$ & 0.17 & $0.056-0.09$ & 0.067 \\
\hline 3 & $2466-2483$ & 17 & $0.08-0.22$ & 0.14 & $0.049-0.145$ & 0.081 \\
\hline 4 & $2668-2732$ & 64 & $0.11-0.44$ & 0.20 & $0.027-0.088$ & 0.04 \\
\hline
\end{tabular}

\section{Conclusion}

The reservoir potentiality of the Rashidpur well-4 was studied using wireline logs. Based on the composite log response, 20 permeable zones were identified in the study well. Four zones were hydrocarbon bearing and the rest zones contained water. The low GR, high SP, high resistivity, low neutron and low density $\log$ responses indicated that hydrocarbon type was gas. Average porosity was calculated as $22 \%$. Average water saturation ranged from $17-40 \%$ whereas average hydrocarbon saturation ranged from $60-82 \%$. Average BVW of these zones ranged from $0.081-0.13$. These values indicate that the lithologies of these zones are fine to very fine-grained sandstone and hydrocarbon is moveable in the Rashidpur well-4. Average permeability of gasbearing zones was estimated at $207 \mathrm{mD}$. It reveals that all petrophysical parameters have been calculated to characterize the reservoir using wireline log data. The study also reveals that hydrocarbon-bearing reservoir are potential for gas production and accumulation and less effect of shale distribution.

\section{Acknowledgement}

Authors would like to acknowledge the Chairman of Bangladesh Oil, Gas and Mineral Corporation (Petrobangla) and the Managing Director, BAPEX for their kind permission and access to well log data while conducting this research work.

\section{References}

[1] Y.C. Ajisafe, B.D. Ako, 3-D seismic attributes for reservoir characterization of "Y" field Niger Delta, Nigria, IOSR Journal of Applied Geology and Geophysics, 1 (2), 2013, 23-31.

[2] G.B. Asquith, and C.R. Gibson., Basic well log analysis for geologists; (Text book, AAPG, Tulsa, Okalhoma, U.S.A. 1982).

[3] Islam, M.A., Islam, M.S., Latif, M.H., Mondal, D. and M.A. Mahbub, Petrophysical analysis of shaly-sand gas reservoir of Titas Gas Field using well logs, Bangladesh, Journal of Geology, 25, 2006, 106-124.

[4] M.A. Islam,M.S. Islam, D. Mondal, Log derived shaly-sand analysis of Shahbazpur Gas Field, Bhola,Bangladesh; Bangladesh Geoscience Journal, 13, 2007, 63-77.

[5] M. A. Islam, M.S. Islam,S. Talukder,K.E. Haque, M.A. Rahman, F. Ahmed., Petrophysical evaluation of NeogeneShaly-sand gas reservoir: A case study of Kailas Tila Gas Field; Bengal Basin, Bangladesh, International Journal of Earth Science and Engineering, 2, 2009, 499-511.

[6] M.A. Islam, Petrophysical evaluation of subsurface reservoir sandstone of Bengal Basin, Bangladesh, Bangladesh Geoscience Journal, 76, 2010, 621-631.

[7] M.M. Rahman, A.S.M .Woobaidullah, B.Imam and M.M.Rahman, Evaluation of Reservoir Sands of Titas-15 Well by Wireline log interpretation; Bangladesh Geoscience Journal, 15, 2009, 67-75.

[8] M.M., Alam, J.R. Curray, M.L.R. Chowdhury, \& M.R. Gani, An overview of the sedimentary geology of the Bengal Basin in relation to the regional tectonic framework and basinfill history; Sedimentary Geology, 155, 2003,179-208.

[9] K.U., Reimann, Geology of Bangladesh, (GebruderBarntrager, Berlin, Stuttgart, Germany, 1993).

[10] Bangladesh Petroleum Exploration Production Company (BAPEX), Interpretation Report on the greater Bakhrabad Structure; Data Centre, Petrobangla, Dhaka, 1988.

[11] A. Uddin and N. Lindberg, Miocene paleogeography of the Bengal Basin, Bangladesh: Sub-surface lithofacies analysis; Abstracts American Geophysics Union, Spring Meeting, 1995, 52-79.

[12] Schlumberger, Log Interpreation.Volume-II-Principles;( Houston, Schlumberger Well Services Inc., 1974).

[13] Dresser Atlas, Log Interpretation Charts; (Houston, Dresser Industries. Inc., 1979).

[14] R.M. Bateman, and C.E., Konen, The log analyst and the programmable pocket calculator; the log Analyst. 18 (5), 1977, 3-11.

[15] G. Coates, and J.L. Dumanoir, A new approach to improve log-derived permeability; Society of Professional Well Log Analysis, 14th Ann. Logging Symp., Trans., Paper R, 1973.

[16] G.E. Archie, The Electrical Resistivity Log as an aid in determining some reservoir characteristics. Petroleum Technology, 5, 1942, 54-62.

[17] R.L. Morris, and W.P. Biggs, Using log-derived values of water saturation and porosity; Society Professional Well Log Analysis, 8th Ann. Logg.Symp. Trans. Paper O., 1967.

[18] W.H. Fertl, Log-derived evaluation of shaly classic reservoirs; Journal of Petroleum Technology, 1987, 175-193.

[19] N. Ruhovets, A log analysis technique for evaluating laminated reservoir in the Gulf Coast. The log analyst, 31, 1990, 294-303.

[20] M.H. Rider, The geological interpretation of well logs, (Blackie Glasgow and London; John wiley and Sons, Newyork, 1979). 